$1-1995$

\title{
How Industrial Distributors View Distributor-Supplier Partnership Arrangements
}

\author{
W. Benoy Joseph \\ Cleveland State University, W.JOSEPH@csuohio.edu \\ John T. Gardner \\ Sharon Thach \\ Frances Vernon
}

Follow this and additional works at: https://engagedscholarship.csuohio.edu/busmarkt_facpub

Part of the Business Administration, Management, and Operations Commons

How does access to this work benefit you? Let us know!

\section{Original Citation}

Joseph, W. B., Gardner, J. T., Thach, S., , \& Vernon, F. (1995). How Industrial Distributors View DistributorSupplier Partnership Arrangements. Industrial Marketing Management, 24(1), 27-36.

\section{Repository Citation}

Joseph, W. Benoy; Gardner, John T.; Thach, Sharon; and Vernon, Frances, "How Industrial Distributors View Distributor-Supplier Partnership Arrangements" (1995). Marketing. 20.

https://engagedscholarship.csuohio.edu/busmarkt_facpub/20

This Article is brought to you for free and open access by the Browse Business Faculty Books and Publications by Topic at EngagedScholarship@CSU. It has been accepted for inclusion in Marketing by an authorized administrator of EngagedScholarship@CSU. For more information, please contact library.es@csuohio.edu. 


\section{How Industrial}

\section{Distributors View}

Distributor-Supplier

Partnership

Arrangements

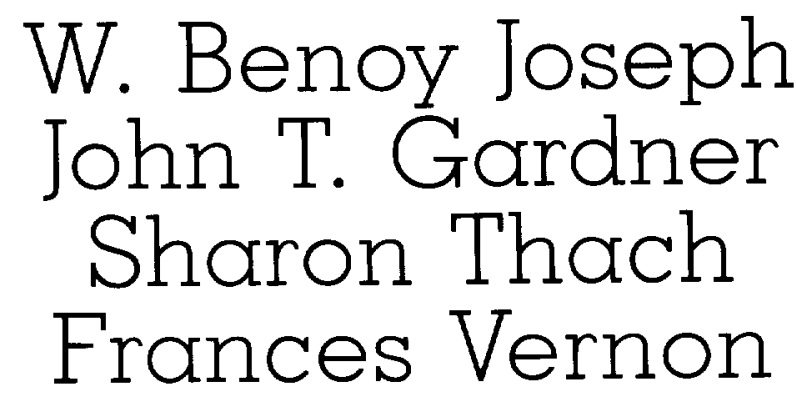

This nationwide survey reports distributors'perspectives of their relationship with a core supplier. The survey reports on elements of partnership, expectations, outcomes, and satisfaction relating to the relationship's position on a continuum between arm's length and close partnership styles.

Address correspondence to W. Benoy Joseph, Department of Marketing, Cleveland State University, 2121 Euclid Ave., Cleveland, OH 44115.

This article is dedicated to the late John R. Cunin, former CEO of Bearings, Inc. The financial support of Bearings, Inc., Cleveland, Ohio, and the cooperation and assistance of the Industrial Distributors Association are gratefully acknowledged.

\section{INTRODUCTION}

The formation of manufacturer-distributor partnerships has recently emerged as a significant trend in marketing channel relationships. Both academic and practitioneroriented literature have drawn attention to the potential of these working relationships as a means of gaining significant competitive advantage. Impressive examples of partnership achievements, along with numerous prescriptions for building successful partnerships, have appeared in the popular press. 


\section{There is little agreement on what makes $\alpha$ partnership successful.}

Partnership-style relationships are characterized by a high degree of coordinated effort and planning, and full sharing of information. Narus and Anderson [16] have stated that a successful partnership is characterized by mutual cooperation, objectives, strategies, and tactics. Mutual interdependence has been identified as a key to successful partnerships [11]. However, partnerships are not necessarily exclusive or contractual relationships, and they must not be confused with the legal business structure called "partnership" [3]. Through mutual cooperation, the partnering firms are able to enjoy many of the benefits of vertical integration such as economies of scale, cost reduction, improved market intelligence, and spreading of risk without the associated disadvantages of large capital expenditures, loss of flexibility, and costly management infrastructure $[9,22]$. Formation of the relationship may be motivated by a desire to improve customer service, or by competitive pressures. Partnerships, however, are not necessarily ideal for every business relationship. Dependence upon a few customers or suppliers can obviously pose a substantial risk to any business [7]. Furthermore, in order to build the relationship, firms may have to invest in what Williamson $[24,25]$ has termed "specific assets," such as specialized communication software or employee training that are not easily transferable to other business uses.

It is generally agreed that partnering arrangements require careful attention and nurturing. Indeed, Shapiro [19]

W. BENOY JOSEPH is Marketing Department Chair at the Nance College of Business Administration, Cleveland State University, Cleveland, Ohio.

JOHN T. GARDNER is Assistant Professor of Marketing at SUNY College-Brockport, Brockport, New York.

SHARON THACH is Associate Professor of Marketing in the College of Business, Tennessee State University, Nashville, Tennessee.

FRANCES VERNON is a doctoral student in marketing at Cleveland State University, Cleveland, Ohio. warns firms not to dissipate managerial energy by establishing too many partnerships. Furthermore, he urges potential partners to consider the compatibility of their respective corporate cultures.

\section{LITERATURE REVIEW}

Current investigations suggest that partnering or strategic alliances result from expectations of mutual benefits in such arrangements $[3,4,9]$. Successful partnerships between manufacturers and distributors include planning and information sharing [19] and investments in specialized information exchange systems such as electronic data interchange $[5,12,21]$. Success is also predicated upon the level of commitment both firms make to the relationship and their understanding of mutual needs $[14,15,16]$.

A firm's expectations, prior to forming a partnership arrangement, may influence the eventual outcome of the relationship. In studying joint ventures, Harrigan [10] attributed a large number of failures to one or more of the following causes: unclear objectives; failure to properly match the capabilities of the respective partners; and unrealistic expectations.

Williamson's $[24,25]$ three critical dimensions of transactions-uncertainty, frequency of transactions, and specificity of assets - have been examined in a variety of settings as factors influencing the development of partnering agreements $[1,11,17,18,23]$. Dependency and conflict have also been studied within existing relationships. For example, Anderson and Narus [1] examined manufacturerdistributor partnerships from the perspective of both parties. Their model, however, focused upon the structure of the relationship rather than the relationship-building process. In this study, as well as in other previous research, factors that may have influenced the choice of relationship style and the nature of the post-choice relationship have not been investigated in a systematic manner.

Other research streams have investigated potential components of partnership arrangements. Macneil [13] identified seven components of contractual relationships between 
firms: (1) commencement, duration, and termination provisions; (2) measurement and specificity; (3) planning; (4) sharing versus dividing benefits and burdens; (5) interdependence, future cooperation, and solidarity; (6) personal relations and numbers; and (7) power, both unilateral and bilateral. However, after reviewing Macneil's schema, Dwyer, Schurr, and Oh [6] suggested that the number of dimensions be reduced to make this framework useful for research on channel relationships.

Gardner, Cooper, and Noordewier [7] reduced Mcneil's set to five behavioral dimensions:

1. Extendedness. The strength of the long-term commitment between the parties; extendedness encompasses loyalty and the commitments to each other made over time.

2. Sharing of benefits and burdens. This dimension is a measure of both parties' willingness to share shortterm losses as well as gains in an equitable manner.

3. Planning. Encompasses the coordination of the two firms through both horizontal and vertical communication links in order to achieve the goals of both firms.

4. Systematic operational information exchange. Involves building joint information systems such as EDI, bar coding, or other types of similar systems.

5. Operating controls. Mechanisms which allow for mutual verification of all operations in both firms which could potentially affect the key dimensions of the relationship.

Gardner and his colleagues [7] found support for the five dimensions with data from a nationwide survey of more than 200 logistics service suppliers. Their framework can be applied to a broad range of partnering relationships.

Despite the widespread interest in partnering arrangements, there appears to be little agreement on the method for identifying the dimensions or key elements of successful relationships. Furthermore, there have been few attempts to determine what factors influence the formation of partnerships, the degree of coalition achieved, and the outcomes of these arrangements. Our study attempts to examine these issues from the perspective of the industrial distributor.

A dyadic study, assessing both distributor and supplier perspectives, has obvious merit. However, we elected to limit our investigation to the industrial distributor because this permits more distributor-specific issues to be explored. This approach was driven also by practical considerations (e.g., availability of lists, limited budget), methodological concerns (e.g., getting matched samples of distributors and suppliers, adequate sample sizes), and conceptual choices (e.g., studying perceptions versus concrete evidence of partnerships). Furthermore, distributor perceptions are significant because if a partnership is perceived to exist, the distributor will act as if there is a partnership.

\section{RESEARCH OBJECTIVES}

Our principal objective was to investigate the industrial distributor's perspective on partnership-style arrangements with suppliers. Specific objectives were to identify:

- Distributors' perceptions, attitudes, experiences, and satisfaction concerning the style of their relationship with a core supplier.

- The conditions that led to or triggered partnership-style arrangements.

- The expectations that distributors had in entering into such arrangements and the outcomes realized.

\section{METHODOLOGY}

The Industrial Distributors Association's U.S. membership list served as the sampling frame for the selection of 1,000 distributors. IDA's membership represents a wide cross-section of industries. However, a majority of its members serve automotive, construction, metal working, electrical/electronic, aircraft, chemicals, and institutional markets.

The survey instrument was developed from previous findings in the literature and from a theoretical model of the structure and process of relationship-building between distributors and suppliers [8]. The general objective was to study distributors' perceptions of the antecedents and consequences of distributor-supplier partnership arrangements. The instrument was pretested with five distributors and two experienced consultants serving the industrial distribution industry.

Surveys were mailed to distributors and followed three weeks later with a reminder postcard. A final sample of 221 completed surveys was obtained, a response rate of $22 \%$.

\section{Who Responded}

The sample consisted of a representative cross-section of IDA members nationwide. Service areas and annual sales of distributor respondents are summarized in Table $1 . \mathrm{A}$ profile of the sample shows:

- Nearly nine out of ten distributors surveyed (87\%) operate within a multicounty or multistate area. 


\section{Mutual loyalty is a hallmark of strong partnerships.}

- More than half (54\%) have annual sales of less than $\$ 5$ million; $24 \%$ sell $\$ 5$ to $\$ 10$ million; $20 \%$ sell between $\$ 10$ and $\$ 50$ million; and $2 \%$ sell more than $\$ 50$ million.

- The number of customers served ranges from 10 to 28,000 , with a median of 900 .

- The number of product lines carried ranges from 3 to 25,000 (median: 75; mean: 275). The median number of stock keeping units (SKUs) or items carried is 10,000 .

\section{FINDINGS}

\section{How Common Are Partnership Arrangements?}

Respondents were asked to choose a "core" supplier (one who was important but not necessarily their largest supplier) and describe the style of their relationship with this supplier on a seven-point scale $(1=$ strong partnership style to $7=$ very "arm's-length" style).

Nearly eight out of 10 distributors surveyed (79\%) described their relationship styles with their core suppliers

TABLE 1

Characteristics of Distributor Respondents

\begin{tabular}{lccc}
\hline & $\begin{array}{c}\text { Total } \\
\text { Sample }\end{array}$ & $\begin{array}{c}\text { Strong } \\
\text { Partnership }\end{array}$ & $\begin{array}{c}\text { Arm's Length } \\
\text { Relationship }\end{array}$ \\
\hline $\begin{array}{l}\text { Territory served by } \\
\text { distributor }\end{array}$ & & & \\
$\begin{array}{l}\text { Metro area } \\
\text { Multicounty }\end{array}$ & $8 \%$ & $8 \%$ & $6 \%$ \\
$\quad$ Multistate & $56 \%$ & $57 \%$ & $56 \%$ \\
National & $31 \%$ & $29 \%$ & $33 \%$ \\
International & $3 \%$ & $2 \%$ & $2 \%$ \\
& $n=218$ & $n=163$ & $n=47$ \\
& & $3 \%$ & $2 \%$ \\
Annual sales & & & \\
$\$ 1,000,000$ or less & $4 \%$ & $4 \%$ & $6 \%$ \\
$\$ 1,000,000-\$ 5,000,000$ & $50 \%$ & $49 \%$ & $51 \%$ \\
$\$ 5,000,000-10,000,000$ & $24 \%$ & $23 \%$ & $23 \%$ \\
$\$ 10,000,000-50,000,000$ & $20 \%$ & $21 \%$ & $19 \%$ \\
$\$ 50,000,000-100,000,000$ & $1 \%$ & $1 \%$ & $0 \%$ \\
More than $\$ 100,000,000$ & $1 \%$ & $2 \%$ & $0 \%$ \\
& $n=212$ & $n=163$ & $n=47$ \\
\hline
\end{tabular}

as being moderate to strong partnership (with scores of 4 or less on the seven-point partnership scale). This evidence empirically confirms the growing popularity of partnershipstyle arrangements in distribution channels.

\section{Factors Influencing Partnership Styles}

Distributors were asked to rate the importance of the factors that had influenced the style of the relationship arrangement with their core suppliers when the relationship was "initiated, reviewed, or revamped." Importance ratings were obtained on a seven-point scale $(1=$ very important to $7=$ very unimportant).

Table 2 shows that long run survival and competitive pres-

\section{TABLE 2}

Influencing Factors When the Relationship Was Initiated, Reviewed, or Revamped

\begin{tabular}{|c|c|c|c|c|}
\hline & \multicolumn{2}{|c|}{$\begin{array}{c}\text { Strong } \\
\text { Partnership }\end{array}$} & \multicolumn{2}{|c|}{$\begin{array}{l}\text { Arm's Length } \\
\text { Relationship }\end{array}$} \\
\hline & Mean & SD & Mean & SD \\
\hline \multicolumn{5}{|l|}{ This relationship was ${ }^{\mathrm{a}}$} \\
\hline \multicolumn{5}{|l|}{ The result of demands } \\
\hline of our customers & 3.50 & 1.87 & 3.17 & 1.57 \\
\hline \multicolumn{5}{|l|}{ The result of demands by } \\
\hline this [core] supplier ${ }^{b}$ & 4.02 & 1.79 & 4.45 & 1.69 \\
\hline \multicolumn{5}{|l|}{ Necessitated by } \\
\hline competitive pressures & 2.86 & 1.60 & 2.70 & 1.20 \\
\hline \multicolumn{5}{|l|}{ A requirement for our } \\
\hline \multirow[t]{2}{*}{ long run survival } & 2.06 & 1.20 & 2.08 & 1.22 \\
\hline & \multicolumn{2}{|c|}{$\begin{array}{l}\text { Total } \\
\text { Sample }\end{array}$} & $\begin{array}{c}\text { Strong } \\
\text { Partnership }\end{array}$ & $\begin{array}{l}\text { Arm's } \\
\text { Length }\end{array}$ \\
\hline \multicolumn{5}{|l|}{$\begin{array}{c}\text { Which one of the above was } \\
\text { the primary influence? }\end{array}$} \\
\hline Our customers & \multicolumn{2}{|c|}{$32 \%$} & $30 \%$ & $40 \%$ \\
\hline This supplier & \multicolumn{2}{|c|}{$17 \%$} & $18 \%$ & $13 \%$ \\
\hline Competitive pressures & \multicolumn{2}{|c|}{$16 \%$} & $13 \%$ & $21 \%$ \\
\hline Long run survival & \multicolumn{2}{|c|}{$32 \%$} & $36 \%$ & $21 \%$ \\
\hline \multirow[t]{2}{*}{ Other } & \multicolumn{2}{|c|}{$3 \%$} & $3 \%$ & $2 \%$ \\
\hline & \multicolumn{2}{|c|}{$100 \%$} & $100 \%$ & $100 \%$ \\
\hline
\end{tabular}

${ }^{a}$ The responses to the items in this section were coded as 1 (very important) to 7 (very unimportant).

${ }^{b}$ Means are significantly different between the two groups at $p<.05$. 
sures were rated as important by all distributors, regardless of their relationship style with their core supplier. However, when respondents were forced to name one factor as the primary influence, long run survival (36\%) and customer demands (30\%) were cited most frequently among distributors with strong partnership styles (Table 2). Among distributors in arm's-length style relationships with core suppliers, customer demands were rated as most important.

\section{Elements of Partnership}

Distributors were asked to identify the elements of their business relationship with core suppliers by agreeing or disagreeing with 18 relationship statements (e.g., "There is much mutual loyalty between our firms") and indicating if five practices (e.g., "The supplier monitors our systems to insure overall efficiency") were present in their relationship. Agreement items were assessed with a seven-point scale $(1=$ strongly agree to $7=$ strongly disagree $)$. Presence of certain practices (e.g., sharing of market forecasts or customer information) was assessed with a different seven-point scale $(1=$ always to $7=$ never $)$.

What are the business relationship elements that distributors believe to be present in strong partnerships? Which elements correlate with general satisfaction with the core supplier? Table 3 answers these questions, reporting the correlations between business relationship elements and various measures. The results are classified into four correlation levels: strongest $(r=.4$ or more), moderate $(r=$

TABLE 3

How Strength of the Partnership with Supplier and Satisfaction with the Relationship Are

Correlated with Elements of the Business Relationship

\begin{tabular}{|c|c|c|}
\hline \multirow[b]{2}{*}{ Business Relationship Elements } & \multicolumn{2}{|c|}{ Correlation with Partnership } \\
\hline & $\begin{array}{l}\text { Strength } \\
(n=221)\end{array}$ & $\begin{array}{l}\text { Satisfaction } \\
(n=221)\end{array}$ \\
\hline \multicolumn{3}{|l|}{ Strongest relationships } \\
\hline There is much mutual loyalty & .72 & .79 \\
\hline The supplier will help in a difficult situation & .58 & .66 \\
\hline We do more joint planning & .48 & .48 \\
\hline We are more likely to help this supplier & 48 & .51 \\
\hline We expect a long-term relationship & .43 & .55 \\
\hline We have more face-to-face communications & .42 & .42 \\
\hline Supplier will favor our prime customers & .42 & .39 \\
\hline \multicolumn{3}{|l|}{ We balance supplier production with } \\
\hline our inventory needs & .40 & .40 \\
\hline \multicolumn{3}{|l|}{ Moderate relationships } \\
\hline We share market information with one another & .38 & .39 \\
\hline We share customer information & .38 & .35 \\
\hline \multicolumn{3}{|l|}{ We will support this supplier's products } \\
\hline during shortages & .34 & .27 \\
\hline \multicolumn{3}{|l|}{ We have more joint task forces than with } \\
\hline other suppliers & .31 & .28 \\
\hline Supplier shares risks & .28 & .27 \\
\hline We have developed joint information systems & .28 & .32 \\
\hline We coordinate value added steps & .21 & 19 \\
\hline We monitor the supplier's systems & .20 & .15 \\
\hline \multicolumn{3}{|l|}{ We use specific goals to monitor } \\
\hline this relationship & .20 & .25 \\
\hline \multicolumn{3}{|l|}{ Weak relationships } \\
\hline Supplier has financial commitment to our firm & .16 & .14 \\
\hline Long-term contract present & .16 & - \\
\hline Supplier monitors our system & .13 & - \\
\hline \multicolumn{3}{|l|}{ No measurable relationships } \\
\hline $\begin{array}{l}\text { This relationship offers a broader range of } \\
\text { products than usual }\end{array}$ & - & - \\
\hline We have many computer-to-computer links & - & - \\
\hline We use compatible software & - & - \\
\hline
\end{tabular}

All Pearson correlation coefficients shown are significant at the .05 level. Partnership strength is coded as 1 (strong partnership) to 7 (very arm's length). Distributor's satisfaction with current core supplier relationship is coded as 1 (very satisfied) to 7 (not at all satisfied). 


\section{Strong partnerships can improve distributors' relations with their customers.}

.2 to .39 ), weak $(r<.2)$, and not measurable (not statistically significant).

The Strongest Elements. Distributors in strong partnership-style arrangements view the presence of mutual loyalty between them and their core suppliers as a strong characteristic of their relationship $(r=.72)$. Other strong elements of partnership include the expectation that partners will help each other in difficult situations, and that more joint planning is done.

The Weakest Elements. Contrary to expectations, some arrangements are uncorrelated or weakly correlated with the presence of strong partnerships. For example, compatible software, computer-to-computer links, and long-term contracts-elements one would expect in partnership arrangements today - were uncorrelated with the strength of the partnership style. This leaves an open question as to how certain information linkages influence partnership building. Some possible explanations are that industrial distributors have found alternative information systems (e.g., fax-based), or that such technologies may be common among all styles of relationships, or may not have penetrated this environment sufficiently. Indeed, our survey found that compatible software and computer-to-computer links were not common.

Weak correlations were also noted for three elements. These were financial commitments by the supplier, presence of long term contracts, and supplier monitoring of the distributor's system.

\section{Satisfaction with the Relationship}

The survey assessed global satisfaction with the relationship with a single measure $(1=$ very satisfied to $7=$ not at all satisfied). The second column in Table 3 reports correlation coefficients between individual elements and global satisfaction. The findings suggest that the strongest partnership elements were also the strongest influences on satisfaction with the relationship.

Notable for their high correlations were elements such as mutual loyalty, supplier helping in a difficult situation, and expectations of a long term relationship. In notable contrast is the much lower correlation between satisfaction and helping suppliers during shortages. Understandably, it is much more satisfying to receive than to give.

\section{Expectations and Outcomes}

The correspondence between expectations and outcomes is important in understanding the dynamics of partnership building. Early in the survey, distributors were asked to rate their expectations for the relationship with the core supplier when it was initiated or revamped. Toward the end of the survey, outcomes were assessed. Expectation and outcome items, by design, were not identical in order to minimize response bias. Expectation questions were more specific whereas outcome questions were more global.

Expectations. Table 4 summarizes the likelihood of specific expectations being met $(1=$ very likely to $7=$ very unlikely). The results are reported for two groups:

TABLE 4

Relationship Expectations of Distributors in Strong Partnerships Versus Arm's Length Relationships

\begin{tabular}{|c|c|c|c|c|}
\hline & \multicolumn{2}{|c|}{$\begin{array}{c}\text { Strong } \\
\text { Partnership }\end{array}$} & \multicolumn{2}{|c|}{$\begin{array}{l}\text { Arm's Length } \\
\text { Relationship }\end{array}$} \\
\hline & Mean & $\mathrm{SD}$ & Mean & $\mathrm{SD}$ \\
\hline \multicolumn{5}{|l|}{ This relationship would ${ }^{\mathrm{a}}$} \\
\hline $\begin{array}{l}\text { Yield better customer service } \\
\text { for our customers }\end{array}$ & 2.04 & 1.13 & 3.06 & 1.58 \\
\hline $\begin{array}{l}\text { Yield lower total costs for } \\
\text { our customers }\end{array}$ & 3.53 & 1.88 & 4.00 & 1.69 \\
\hline $\begin{array}{l}\text { Yield an improved range of } \\
\text { products for our customers }\end{array}$ & 2.95 & 1.74 & 2.69 & 1.60 \\
\hline $\begin{array}{l}\text { Yield improved overall quality } \\
\text { for our product offering }\end{array}$ & 2.84 & 1.58 & 2.98 & 1.52 \\
\hline $\begin{array}{l}\text { Yield lower prices for our } \\
\text { customers }\end{array}$ & 4.31 & 1.86 & 4.35 & 1.88 \\
\hline $\begin{array}{l}\text { Yield increased customer satis- } \\
\text { faction with our offering }\end{array}$ & 2.11 & 1.15 & 2.74 & 1.61 \\
\hline $\begin{array}{l}\text { Protect our investment in assets } \\
\text { specific to this account (e.g., } \\
\text { special equipment or systems) }\end{array}$ & 3.15 & 1.77 & 3.98 & 1.87 \\
\hline
\end{tabular}


Distributors in strong partnership style versus those in arm's length relationships.

Distributors with strong partnerships expected customer service improvements, protection of specific assets, and increased customer satisfaction to a greater degree than those with arm's length relationships. In contrast, partnership style did not appear to influence expectations of improved overall quality, improved range of products, or lower prices.

Outcomes. The results achieved with the relationship were measured by six items covering profitability, efficiency, and external relationships (see Table 5). Distributors in strong partnership arrangements, in contrast to those in arm's length relationships, realized more profits from the core supplier's account and complementary lines of trade. Strong partnership distributors also experienced more managerial efficiencies but applied more managerial effort and time to the core supplier account.

Partnership arrangements appear to influence distributor relationships with other suppliers and with customers. Strong partnership-style distributors report more negative impact on their relations with other suppliers. This is understandable because competing suppliers will be at a disadvantage when their distributor-customer has formed strong ties with another supplier. On the other hand, strong

\section{TABLE 5}

Results Achieved in Relationship with Core Supplier for Distributors in Partnership versus Arm's Length Relationships

\begin{tabular}{|c|c|c|c|c|}
\hline \multirow[b]{2}{*}{ Results Achieved ${ }^{3}$} & \multicolumn{2}{|c|}{$\begin{array}{c}\text { Strong } \\
\text { Partnership }\end{array}$} & \multicolumn{2}{|c|}{$\begin{array}{l}\text { Arm's Length } \\
\text { Relationship }\end{array}$} \\
\hline & Mean & SD & Mean & SD \\
\hline $\begin{array}{l}\text { This supplier account allows us to } \\
\text { make more profit from comple- } \\
\text { mentaty lines of trade }\end{array}$ & 3.00 & 1.41 & 4.23 & 1.61 \\
\hline $\begin{array}{l}\text { This account enables our manager } \\
\text { to manage our business more } \\
\text { efficiently }\end{array}$ & 3.27 & 1.42 & 4.67 & 1.46 \\
\hline $\begin{array}{l}\text { This account expends more man- } \\
\text { agerial effort and time than a } \\
\text { typical account }\end{array}$ & 3.24 & 1.60 & 4.02 & 1.95 \\
\hline $\begin{array}{l}\text { This account is more profitable that } \\
\text { other accounts we have }\end{array}$ & 2.96 & 1.34 & 4.52 & 1.65 \\
\hline $\begin{array}{l}\text { Working with this supplier has } \\
\text { a negative impact on relations } \\
\text { with other suppliers }\end{array}$ & 5.64 & 1.47 & 4.92 & 1.60 \\
\hline $\begin{array}{l}\text { Working with this supplier has } \\
\text { had a negative impact on rela- } \\
\text { tions with our customers }\end{array}$ & 6.37 & 1.05 & 5.56 & 1.53 \\
\hline
\end{tabular}

${ }^{a}$ Responses to these items were coded as 1 (strongly agree) to 7 (strongly disagree).

${ }^{b}$ Means are significantly different between the two groups at $p<.05$. partnership appears to improve a distributor's relations with its customers.

When compared with their expectations, distributorreported experiences (outcomes) reveal interesting insights about the way partnerships evolve. In initiating or revamping a relationship, distributors expected partnerships to yield better customer service and increased customer satisfaction. These expectations appear to be realized in improved customer relations. Also, expectations about specific asset protection square with more profitable outcomes reported by strong partnership distributors.

\section{How Satisfied Are Distributors with Supplier Partners?}

In order to permit comparison between distributors in partnership versus arm's length-style relationships with their core supplier, we divided the sample into two groups: Partnership-style distributors (those who rated their relationship with their core supplier as 4 or less; $n=171$ ) and arm's length-style (those with self-ratings greater than 4; $n=48$ ). The two groups were compared on a seven-point global measure of satisfaction with their core supplier $(1=$ very satisfied to $7=$ not at all satisfied).

Results showed that partnership-style distributors are significantly more satisfied with their core supplier (mean = 2.1) than are distributors in arm's length relationships (mean $=4.1 ; p<.001$ ). This is not surprising. As Table 5 shows, distributors in partnership-style relationships with their core suppliers realize many benefits that distributors in arm's length relationships do not.

\section{IMPLICATIONS AND CONCLUSIONS}

\section{Implications for Distributors}

Perception of customer needs and demands seem to be the most influential factor in determining the style of relationship between distributor and supplier. However, those with stronger partnering arrangements report more pressure toward close ties in order to ensure survival. This indicates that future research should explore the difference in either circumstance or perception that leads to a difference in the relationship style. The connection between customer demands and partnership for survival is also worthy of further exploration. It is possible to speculate on industry reorganization having an effect on all members of the channel, so that customer expectations are generated by the outcomes of various distributive arrangements and these in turn feed perceptions of customer needs, which require 


\section{Suppliers with distributor partners gain a competitive advantage.}

a certain type of structure. The reported movement toward closer relationships may reflect changes in all participants' expectations, thus generating more pressure toward change.

Although a majority of distributors reported more partnering-style relationships, the actual activity reported suggests that the relationship is manifested more in distributor attitudes than in actual behaviors. For example, the strongest relationships with partnering were for items reflecting goodwill and beliefs about potential support. Far weaker correlations were reported for activities such as information sharing, coordinating value-added steps, and development of joint information systems.

This dichotomy between words and deeds suggests that either trust is a precursor of specific activities and that these relationships are too new for the implementation of shared business operations, or that many managers feel pressures toward having "modern" business arrangements and have simply changed their perceptions but not their practices. The importance of facilitating technology is also important. Integrated planning and information sharing may be dependent on certain technologies that themselves are not accepted, valued, or needed. Change in technologies or their use may not occur until the need to invest in the relationship forces a reevaluation. Alternatively, the availability of technological support may lead to deeper levels of shared activity. The consistency of satisfaction correlations with partnership correlations supports the attitudinal explanation more than the technological one.

\section{Implications for Suppliers}

Suppliers wishing to explore the potential for partnering relationships with their distributions or review existing relationships should consider the following actions suggested by the results of our survey.

Express Loyalty Through Actions. Distributors value loyalty among partners. Suppliers should nurture desirable partnerships with special relationship-enhancing strategies, actions, and symbolic gestures (e.g., preferred delivery schedules, allowances, discounts, and personal contacts) that send clear messages to distributor partners that they are special. When distributor partners encounter difficul- ties or setbacks, the supplier should take reasonable steps to help them.

Strengthen Partnerships to Deter Competitors. Our results suggest that a strong partnership-style relationship weakens a distributor's relations with other suppliers. Hence, strengthening ties with a strong distributor can translate into a competitive advantage.

Assess Internal Capabilities. Suppliers must assess their readiness to undertake the relationship-building process and willingness to commit necessary resources. Our survey indicates that partnerships demand more management time and attention and more joint planning with suppliers than do arm's length relationships, Distributors also said they expected the partnering arrangement to improve customer service and satisfaction. Unless the supplier can demonstrate how such a relationship will achieve these objectives, it is unlikely that the distributor will want to forge a closer relationship with that supplier.

Evaluating and Terminating Current Distributor Partnerships. Regular evaluations can reveal if the partnership is meeting distributor as well as supplier expectations. Periodic assessments of customer as well as distributor satisfaction with various dimensions of the product or service can provide the supplier with early warnings of potential problems that can undermine the partnership. For example, improved customer service ratings by end-use customers can mean that the partnership arrangement is succeeding.

But not all partnerships are worth preserving. When key indicators of partnership well-being show weaknesses (e.g., unilateral actions by distributor that impact on supplier's business; erosion of mutual loyalty and trust), a more careful review of the partnership is warranted. Whereas long-term relationships should be terminated only after careful analysis, preserving such relationships are counterproductive if the distributor's goals and expectations are no longer compatible with those of the supplier.

\section{Scope and Limitation of Study}

The empirical methodology of this study featured objective assessment of the nature of distributor-supplier rela- 
tionships. The IDA membership list provided a sampling frame that included a wide range of industries and sizes of firms in industrial distribution. This permits broader generalizations to be made from this study, compared to case studies and informal observations. However, because our survey was limited to U.S. distributors, caution must be exercised in drawing conclusions about global distribution practices.

A substantial body of research has explored power and conflict issues in partnership building [e.g., 2]. Whereas this approach is valid, alternative paradigms need to be explored. Our study utilized Mcneil's relational contract concept [13] and Williamson's transaction cost approach $[24,25]$.

\section{Major Contributions of the Study}

This study assessed distributors' views on the partnershipbuilding process. The national survey identified the principal influencing factors, expectations, elements of partnership, and outcomes. Differences between strong and weak partnerships were explored across the partnershipbuilding process.

Survey results offer distributors and suppliers a differentiated list of potential partnership-building concerns. For example, in choosing elements to incorporate into a partnership, our study revealed that face-to-face communications were consistently related to strong partnerships, whereas computer-to-computer links was not.

\section{Future Research}

This study examined the distributor's perspective. An alternative approach would be to simultaneously examine the partnership-building process from the perspective of each value chain member. Going beyond the dyadic approach, which examines the supplier's and distributor's perspectives, the value chain approach would also include the customer's perspectives. Another possible avenue for further study would be an analysis of how distributors choose between partnership opportunities, and what strategies they might choose in building a portfolio of relationships. Alternative managerial models of relationship portfolio building could be developed (e.g., what mix of arm's length versus strong partnership styles is optimal, and under which conditions would some styles flourish).

\section{Conclusion}

Building good quality business relationships are vital to successful channel management and business success. A high quality relationship is one that matches the needs of both parties as well as the demands of the value chain. This relationship may be arm's length, extremely close, or somewhere in between. Getting it right is the issue.

\section{REFERENCES}

1. Anderson, E., and Weitz, B. A., Make or Buy Decisions: Vertical Integration and Marketing Productivity, Sloan Management Review 27, 3-19 (1986).

2. Anderson, J. C., and Narus, J. A., A Model of Distributor Firm and Manufacturer Firm Working Partnerships, Journal of Marketing 54, 42-58 (1990).

3. Bowersox, D. J., Logistical Partnerships. In Partnerships: A Natural Evolution in Logistics, Logistics Resource, Inc., Cleveland, 1988

4. Bowersox, D. J., and Murray, R. J., Logistics Strategic Planning for the 1990s, Annual Conference Proceedings, Council of Logistics Management, 231-243 (1987).

5. Davis, D., WINS is On-Line, Distribution 83, 94 (November, 1984)

6. Dwyer, R. F., Schurr, P. H., and Oh, S. Developing Buyer-Seller Relationships, Journal of Marketing 51, 11-27 (1987).

7. Gardner, J. T., Cooper, M. C., and Noordewier, T. G., Understanding Shipper-Carrier and Shipper-Warehouser Relationships: Partnerships Revisited, Journal of Business Logistics 15, 121-144 (1994).

8. Gardner, J. T., Joseph, W. B., and Thach, S., Modeling the Continuum of Relationship Styles Between Distributors and Suppliers, Journal of Marketing Channels 2, 1-28 (1993).

9. Johnston, R., and Lawrence, P. R., Beyond Vertical Integration-The Rise of the Value-Adding Partnership, Harvard Business Review 88, 94-108 (1988)

10. Harrigan, K. R., Strategies for Joint Ventures, Free Press, 1985

11. Heide, J., and John, G., The Role of Dependence Balancing in Safeguard ing Transaction-Specific Assets in Conventional Channels, Journal of Mar keting 52, 20-35 (1988)

12. Lorincz, J. A., Getting There with EDI, Purchasing World 29, 58, 60 (November 1985).

13. Macneil, 1. R., Economic Analysis of Contractual Relations: Its Shortfalls and the Needs for a Rich Classificatory Analysis, Northwestern University Law Review 75, 1018-1063 (1981).

14. Narus, J. A., and Anderson, J. C., Turn Your Industrial Distributors into Partners, Harvard Business Review 64, 66-71 (March-April 1986).

15. Narus, J. A., and Anderson, J.C., Distributor Contributions to Partnerships with Manufacturers, Business Horizons 30, 34-42 (September-October. 1987)

16. Narus, J. A., and Anderson, J. C., Strengthen Distributor Performance Through Channel Positioning, Sloan Management Review 29, 31-40 (Winter 1988).

17. Noordewier, T. G., John, G., and Nevin, J. R., Performance outcomes of Purchasing Arrangements in Industrial Buyer-Vendor Relationships, Journal of Marketing 54, 80-93 (1990).

18. Palay, T., Comparative Institutional Economics: The Governance of Rail Freight Contracting, Journal of Legal Studies 13, 6-17 (1984).

19. Reddy, N. M., and Marvin, M. P., Developing a Manufacturer-Distributor Information Partnership, Industrial Marketing Management 15, 157-163 (1986)

20. Shapiro, B. P., Close Encounters of the Third Kind: The Latest Selling Revolution. Unpublished Manuscript, Harvard University. Boston (1985)

21. Skagen, A. E., Nurturing Relationships, Enhancing Quality with Electronic Data Interchange, Management Review 78, 28-32 (February 1989). 
22. Thackray, J., America's Vertical Cutback, The McKinsey Quarterly 74, 41-51 (1986).

23. Walker, G., Strategic Sourcing, Vertical Integration, and Transaction Costs, Interfaces 18, 62-73 (1988).
24. Williamson, O. E., The Economics of Organization: The Transaction Cost Approach, American Journal of Sociology 87, 548-67 (1981).

25. Williamson, O. E., The Economic Institutions of Capitalism, The Free Press, New York, 1985. 